\title{
STRATEGI PENINGKATAN MUTU PERGURUAN TINGGI UNTUK PENGUATAN DAYA SAING MENGHADAPI MASYARAKAT EKONOMI ASIA TENGGARA:STUDI KASUS
}

\author{
Rorim Panday \\ Program studi Teknik Geodesi, Universitas Pakuan \\ J1. Pakuan Bogor, Indonesia \\ Email: indripan@gmail.com
}

\begin{abstract}
Abstrak - Dengan diberlakukannya Asean Economic Community, maka menjadi tantangan bagi Indonesia untuk mempersiapkan diri dalam kegiatan ekonomi, bisnis hingga pendidikan. Salah satunya melakukan penguatan daya saing pada pendidikan tinggi, dengan cara peningkatan mutunya. Sebagai instrumen untuk peningkatan mutu Perguruan Tinggi adalah melakukan evaluasi mutu internal Perguruan Tinggi menggunakan instrumen Evaluasi Mutu Internal Perguruan Tinggi (EMI-PT). Dengan instrumen ini Perguruan Tinggi dapat melakukan evaluasi diri mutu internalnya guna penjaminan mutunya, sehingga tercapailah peningkatan mutu yang terus menerus (continuous improvement). Instrumen EMI-PT terdiri dari 11 standar pendidikan yang mengacu pada Standar Nasional Pendidikan Tinggi, BAN-PT, AUN dan praktik terbaik pengelolaan Perguruan tinggi. Tujuan dari penelitian ini adalah untuk menunjukkan proses mendapatkan strategi peningkatan mutu perguruan tinggi. Dengan studi kasus pada perguruan Tinggi ABC di Sumatera Barat, menggunakan metode Focus Group Disscussion (FGD), dihasilkan temuan Evaluasi Mutu Internal menunjukkan bahwa di dalam pelaksanaan perguruan tinggi masih terdapat beberapa kekurangan yaitu pada standar proses, standar sarana dan prasarasarana, standar penilaian, standar penelitian, standar pengabdian pada masyarakat dan standar kerja sama. Berdasarkan hasil tersebut maka strategi peningkatan mutu untuk penguatan daya saing yang dapat dilakukan adalah: membentuk unit pengkajian dan pengembangan sistem dan mutu pembelajaran, meningkatkan ketersediaan sarana dan prasarana pendidikan termasuk pembuatan e library, memperbaiki dan meningkatkan sistem evaluasi hasil belajar dengan ranah kompetensi lulusan yang ditetapkan, memotivasi dosen melakukan penelitian dan pengabdian pada masyarakat dengan meningkatkan kemampuan menelitinya, meningkatkan berbagai kerjasama untuk memajukan kualitas pendidikan tinggi, output dan outcome nya.
\end{abstract}

Kata kunci: Evaluasi mutu internal, penjaminan mutu, perbaikan terus menerus, strategi penguatan daya saing.

\section{PENDAHULUAN}

Pada era pasar bebas saat ini bagi Negara anggota ASEAN, kerja sama ASEAN memasuki tahapan berarti, dimana sejak 15 Desember 2008, ASEAN menjadi organisasi regional serta terbentuk sebagai legal personality dengan moto one vision, one identity, one caring and sharing, dengan mencetuskan ASEAN Economic Community (AEC)(Hutabarat, 2014). Konsep utama dari ASEAN Economic Community adalah menciptakan ASEAN sebagai sebuah pasar tunggal dan kesatuan basis produksi dimana terjadi free flow atas barang, jasa, faktor produksi, investasi dan modal serta penghapusan tarif bagi perdagangan antar negara ASEAN yang kemudian diharapkan dapat mengurangi kemiskinan dan kesenjangan ekonomi diantara negara-negara anggotanya melalui sejumlah kerjasama yang saling menguntungkan. ASEAN Community 2015, tentunya memberikan pengaruh bagi sektor pendidikan di Indonesia. Dengan adanya AEC, kesempatan bagi perguruan tinggi asing untuk masuk dan mendirikan di wilayah Indonesia. Hal ini secara peraturan perundang-undangan dimungkinkan sesuai dengan Pasal 90 Undang-undang no 12 tahun
2012 tentang Pendidikan Tinggi yang menyatakan bahwa perguruan tinggi negara lain dapat menyelenggarakan Pendidikan Tinggi di wilayah Indonesia dengan bekerjasama dengan Perguruan Tinggi di Indonesia serta atas izin pemerintah. Kerjasama dapat dilakukan diantara perguruan tinggi di ASEAN seperti halnya yang sudah terbentuk dalam Asian University Network (AUN) dan beberapa perguruan tinggi lainnya sudah menjalin kerjasama dengan perguruan tinggi di regional ASEAN maupun dengan negara-negara lain di Eropa.

Persaingan internasional dalam pendidikan dalam hal: kualitas kompetensi lulusan, kemampuan bahasa internasional/ bahasa inggris, kemampuan bekerjasama, hasil penelitian, program yang dilaksanakan, kemampuan tenaga dosen, dan secara keseluruhan adalah kualitas perguruaan tinggi.

Dengan adanya keadaan yang demikian, maka Indonesia harus bersiap diri untuk dapat bersaing di ASEAN. Potret kualitas pendidikan tinggi di Indonesia masih belum menunjukkan kualitas yang merata. Kualitas perguruan tinggi Indonesia, tercermin dengan lulusannya yang tidak siap pakai, kemampuan bahasa inggris yang rendah, kemampuan bekerjasama 
yang rendah, kemampuan inovasi yang rendah, kreativitas yang rendah, semuanya berujung pada daya saing lulusan yang rendah. Angka pengangguran yang cukup tinggi mencapai 300.000 orang. Lulusan universitas tidak memiliki pengalaman kerja yang cukup.( Organization for Economic Cooperation and Development (OECD) dalam laporan tentang pendidikan tinggi di Indonesia). OECD melansir, universitas di Indonesia termasuk sebagai universitas yang tertinggal. Survei Bank Dunia, yang menyebutkan, 20\%-25\% alumnus perguruan tinggi di Indonesia harus mendapat pelatihan sebelum bekerja (Paramitha, 2012). Hasil temuan Asiaweek 2000 (Nugroho, 2006) menunjukkan daya saing perguruan tinggi di Indonesia rendah. Sangat sedikit perguruan tinggi yang mampu masuk kategori 20 besar di kawasan Asia. Dari 82 PTN dengan 3051 program studi dan 2561 PTS dengan 10287 program studi ternyata sangat sedikit program studi yang bermutu. Masih banyak Perguruan Tinggi Indonesia hanya mentargetkan untuk kuantitas mahasiswa, membuka prodi baru, membuka kelas khusus seperti kelas karyawan, kelas jarak jauh, kelas week end/ kelas sabtu-minggu atau kelas eksekutif. Perguruan Tinggi tersebut menawarkan ijazah dengan cara mengikuti kelas-kelas tersebut tanpa menekankan dari segi kualitasnya. Kelas-kelas seperti itu tidak dirancang untuk mencapai suatu kualitas yang prima, dengan matakuliah yang dipadatkan, dosen pengajar yang sekenanya (seadanya), penyampaian materi yang satu arah, tanpa latihan atau praktek yang benar. Manajemen operasional perguruan tinggi Indonesia masih lemah, kesehatan finansial, kesehatan iklim akademik di kampus juga merupakan faktor penentu keunggulan daya saing (Nugroho, 2006). Sumber finansialnya hanya dari SPP, seharusnya sumber pendapatannya adalah menjual produk berupa ilmu pengetahuan dan segala bentuk aplikasi mutakhir yang bisa dihasilkan dosen dan mahasiswa. Juga berbagai jasa pelatihan yang berhasil mereka kembangkan. Semakin bagus riset dilakukan dan semakin banyak paten yang dihasilkan akan semakin kaya dosen dan perguruannya. Kemampuan dosen untuk melakukan penelitian sangat minim, dan juga dana yang tidak menunjang, kalaupun dana ada di kemdikbud, persoalan adminstratif yang berbelit-belit menjadi hambatan dalam pelaksanaan riset. Perguruan tinggi masih dibebani berbagai tanggung jawab dalam melaksanakan tridharma perguruan tinggi. Perguruan tinggi di Indonesia kurang bisa berperan dalam menyelesaikan berbagai persoalan masyarakat luas, justru asyik dengan diri sendiri, dengan teori-teori yang sudah mapan dan impian-impian yang normatif sehingga menjadi tidak peka terhadap permasalahan di luar. Perguruan tinggi masih minimnya kemampuan dalam menjalin kerja sama dalam konteks global. 9 dari 100 universitas terbaik di Indonesia (100 Universitas Terbaik,2014), masuk dalam 300 peringkat besar Asia (9 Universitas di Indonesia, 2014), dan 29 diantaranya masuk 100 besar Asia Tenggara berdasarkan kriteria webometrik (Sebanyak
29 perguruan tinggi, 2014), dan hanya 4 perguruan tinggi negeri masuk dalam Asean University Network (AUN) (Asean University Network,2014). Perguruan tinggi yang ada di Indonesia ada 3253(data forlap dikti, 2014), berarti kurang dari $1 \%$ yang dapat bersaing di Asia Tenggara. Bagaimanakah dengan perguruan tinggi lainnya? Menurut World Economic Forum, untuk index Higher education and training, Indonesia ranking 64 dari 148 negara di bawah Singapore (rank-2), Malaysia (rank-46), dan Brunai Darussalam (rank-55) sedangkan negara ASEAN lainnya rangkingnya di bawah Indonesia. Times Higher Education menyebutkan, tidak ada satupun dari 92 universitas negeri di Indonesia atau sekitar 3.000 universitas swasta di Indonesia yang masuk dalam deretan 400 institusi perguruan tinggi terbaik dunia. Dengan adanya kondisi tersebut, menjadi masalah utama bagi Indonesia bagaimanakah strategi untuk meningkatkan mutu pendidikan perguruan tinggi dengan diberlakukannya Asean Economic community itu?.

\section{LANDASAN TEORI}

Untuk penguatan daya saing perguruan tinggi Indonesia, maka diperlukan strategi peningkatan mutu pendidikan tinggi, dengan menjalankan peningkatan mutu yang terus menerus (quality improvement continuously). Bagaimana cara sistematis, efektif dan efisien dalam melakukan peningkatan mutu yang terus menerus adalah dengan cara membangun budaya mutu disetiap perguruan tinggi dengan melakukan evaluasi mutu internal secara terus menerus. Dalam hal ini melakukan evalusi terhadap berbagai faktor produksi dalam perguruan tinggi, karena suatu perguruan tinggi pada dasarnya adalah bagian dari pelayanan jasa, yaitu jasa pendidikan. Proses produksi dalam pelayanan jasa pendidikan tinggi dan proses peningkatan mutu pendidikannya dapat dilihat pada gambar-1 seperti yang disampaikan oleh (Panday, 2014b) dan dimodifikasi.

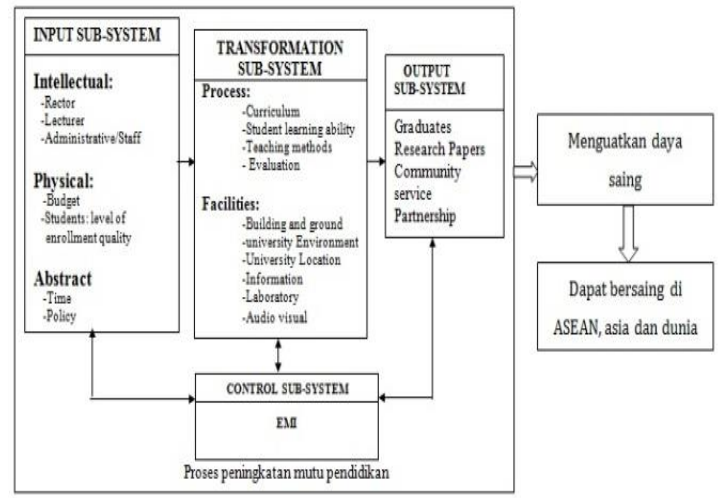

Gambar -1 Konsep peningkatan mutu Pendidikan Tinggi untuk penguatan daya saing

Jasa pendidikan adalah proses transformasi dari faktorfaktor produksi yang menjadi input, kemudian diproses dan menjadi output yang berupa lulusan, hasil penelitian dan pengabdian masyarakat (Panday, 
2014b). Oleh karena itu untuk menjadikan pendidikan yang bermutu perlu diterapkan adanya penjaminan mutu.

Kemdikbud pada tahun 2011 telah membuat instrumen untuk evaluasi mutu internal Perguruan tinggi yang disebut dengan Evaluasi Mutu Internal Perguruan Tinggi (EMI-PT). EMI-PT adalah alat penjaminan mutu Perguruan Tinggi, dan merupakan instrumen yang digunakan untuk mengukur kinerja operasional Perguruan Tinggi dalam menghasilkan lulusan, dan untuk menjamin kualitas lulusan, hasil penelitian, pengabdian masyarakat dan kerjasama (Panday, 2014b), karena komponen dan indikator pada EMI sangat sesuai dengan komponen dan indikator pada gambar-1. EMI telah digunakan oleh (Panday, 2014a) untuk mengevaluasi program studi, menghasilkan analisa SWOT dan rekomendasi untuk peningkatan kualitas program studi dalam menghadapai persaingan globalisasi. Untuk menjamin mutu pendidikan, sebagaimana diamanatkan dalam UU Nomor 20 Tahun 2003 tentang Sisdiknas dan PP No. 19 Tahun 2005 tentang Standar Nasional Pendidikan (SNP), kegiatan sistemik penjaminan mutu penyelenggaraan pendidikan tinggi di perguruan tinggi oleh perguruan tinggi sendiri secara berkelanjutan (continuous improvement) perlu dilakukan.

Substansi EMI-PT, komponen, indikator, tujuan, metode penyusunannya dan cara pelaksanaannya diuraikan dalam (Kementerian Pendidikan dan Kebudayaan, 2012). Berdasarkan pada prinsip PDCA, implementasi EMI yang dilaksanakan setiap tahun akan tercapainya peningkatan kualitas yang terus menerus.

Penelitian ini menggunakan data sekunder yang diambil dari berbagai sumber seperti: internet, Kemdikbud, peraturan dan perundangan yang relevan, dipadukan dengan penelitian kualitatif pada studi kasus Perguruan Tinggi "ABC", yang dilakukan dengan cara Focus Group Discussion (FGD), serupa dengan yang sudah dilakukan oleh (Panday, 2014a), hanya saja untuk penelitian kali ini objek penelitian ini adalah perguruan tinggi. Yang termasuk dalam FGD adalah: struktural prodi, Struktural fakultas, struktural universitas, kepala biro kemahasiswaan, biro administrasi universitas, kepala penelitian dan pengabdian masyarakat, kepala penjaminan mutu, biro IT. Untuk pelaksanaan EMI tersebut mengacu pada (Panday, 2014a).

\section{PEMBAHASAN}

Mengacu data forlap 2014, di Indonesia ada 4587 Perguruan tinggi, terdapat 516 universitas, dimana 58 adalah universitas Negeri dan 458 universitas swasta. Total dosen tetap ada 165.916 dosen dan dosen tidak tetap ada 31.436 dosen. Jumlah mahasiswa yang tecatat ada kurang lebih 3.865.133 orang. Maka rasio dosen tetap jabatan fungsional dosen dan mahasiswa adalah 1: 23,3. Untuk ketentuan rasio rata rata 1:30, maka kondisi yang ada sepertinya telah mencukup, namun pada kenyataan rasio yang terjadi sangat bervariasi pada masing-masing perguruan tinggi. Jika dilihat dari latar belakang pendidikan dosen, maka berdasarkan UU guru dan dosen yang berhak mengajar adalah yang berpendidikan Master (ada 99.120), Doktor (ada 20.029), spesialis-1(2053) dan spesialis-2 (278) sehingga rasio dosen mahasiswa menjadi tidak memenuhi persyaratan SNP.

Jika rasio dosen mahasiswa dihitung terhadap jumlah dosen yang telah disertifikasi sebanyak 71.142 dosen, maka rasionya adalah 1: 54,3 ; dimana rasio ini tidak memenuhi syarat SNP. Sedangkan dosen yang belum bersertifikat sejumlah 94.774 orang. Berarti dalam hal ini masih banyak kuranganya dosen yang bersertifikat. Dari 165.916 dosen tetap, masih ada sekitar 53.693 orang yang belum mempunyai jabatan fungsional dosen dan ada 36.549 masih jabatan asisten ahli.

Dari kondisi dosen di atas, maka kualifikasi dosen berdasarkan pendidikan, jabatan fungsional, dan sertifikasi dosen masih harus ditingkatkan.

Dari kenyataan ini, masih banyak yang harus dilakukan oleh pemerintah Indonesia untuk meningkatkan mutu pendidikan perguruan tingginya. Untuk itu Pemerintah Indonesia telah melakukan pembenahan pada pendidikan tinggi, secara makro, diantaranya membuat Undang-undang guru dan dosen pada tahun 2005, menetapkan anggaran pendidikan dari APBN sebesar 20\%, menetapkan Standar Nasional Pendidikan (SNP), melakukan akreditasi bagi perguruan tinggi, melakukan akreditasi bagi tenaga dosen melalui program sertifikasi dosen, meregistrasi tenaga dosen dengan program nomor induk dosen nasional (NIDN), menertibkan kurikulum nasional, meningkatkan standar kualifikasi fungsional dosen dan lulusan sarjana, magister dan doktor, dan banyak lagi diperkuat dengan peraturan menteri kemdikbud dan kepegawaian Indonesia. Demikian banyak hal yang telah dilakukan sejak tahun 2005, namun belum banyak perguruan tinggi Indonesia yang dapat bersaing di ASEAN, asia dan dunia. Singapore adalah satu satunya negara ASEAN yang masuk 100 besar dunia yaitu National University of Singapore dan Nanyang Technological University, menurut versi Times Higher Education's world reputation ranking of universities. Dari kenyataan yang demikian, secara mikro, perlu adanya peningkatan mutu perguruan tinggi dengan cepat, Untuk itu perlu dilakukan pemetaan mutu perguruan tinggi. Instrument yang dapat digunakan untuk pemetaaan mutu adalah dengan menerapkan EMI-PT. Dengan mengambil studi kasus perguruan tinggi "ABC", berikut adalah hasil akhir dari Evalusi mutu internal suatu Perguruan Tinggi "ABC" tersebut, yang berupa rekap skor yang diperoleh dan gambar grafik dari skor tersebut. Nilai skor per standar dalam skala 0 s/d 100. Rekap skor Mutu Perguruan Tinggi dapat dilihat pada tabel 1 . Standar Isi mendapat sebutan lebih dari cukup. Standar Proses perbaikan minor, Standar Kompetensi lulusancukup, Standar Pendidik dan Tenaga Kependidikan lebih dari cukup, Standar Sarana dan Prasarana perbaikan menyeluruh dan mendesak, dan Standar 
Seminar Nasional Ekonomi dan Bisnis (SNEB) 2014

Pengelolaan-cukup. Standar Pembiayaan- lebih dari cukup, Standar penilaian-perbaikan minor, dan Standar Pengabdian kepada Masyarakat-perbaikan minor. Standar Penelitian mendapat sebutan perbaikan mayor, sedangkan Standar Kerja sama memperoleh sebutan perbaikan mayor. Secara nilai rata-rata standar memperoleh nilai 48,05 dengan sebutan cukup. Mengacu pada nilai rata-rata, ada 5 standar di atas nilai rata-rata dan ada 6 standar di bawah nilai rata-rata. Nilai yang terendah adalah Standar Sarana dan prasarana, sedangkan nilai yang tertinggi adalah Standar Isi, Standar Pendidikan dan Tenaga Kependidikan dan Standar Pembiayaan. Gambar 2 memperlihatan nilai skor standar dalam grafik labalaba. Dari grafik sangat jelas terlihat mana saja standar yang di atas nilai rata-rata dan standar yang di bawah nilai rata-rata. Dengan melihat pada grafik saja seorang pembuat keputusan sudah dapat melihat secara jelas kondisi mutu dari perguruan tinggi, sehingga sudah dapat dengan segera menentukan langkah apa yang diperlukan untuk memperbaiki mutu yang ada.

Table 1. Hasil kualitas nilai Standar

\begin{tabular}{lcl}
\hline \multicolumn{1}{c}{ Standar } & $\begin{array}{c}\text { Skor per } \\
\text { Standar }\end{array}$ & Derajat \\
\hline A. Stand ar isi & 71,43 & Lebih dari Cukup \\
B. Standar Process & 42,86 & Perbaikan minor \\
C S tandar Kel ulusan & 57,14 & Cukup \\
$\begin{array}{l}\text { D Standar pendidikan dan tenaga } \\
\text { kependidikan }\end{array}$ & 71,43 & Lebih dari Cukup \\
E Stand ar sarana dan prasarana & 14,29 & Perbaikan menyeluruh dan mendesak \\
F Standar Pengelolaan & 57,14 & Cukup \\
G Standar Pembiayaan & 71,43 & Lebih dari Cukup \\
H Standar Penilaian & 42,86 & Perbaikan minor \\
IS tandar Penditian & 28,57 & Perbaikan mayor \\
I Standar Pengabdian masyarakat & 42,86 & Perbaikan minor \\
K Standard Kerjasama & 28,57 & Perbaikan mayor \\
\hline Average & 48,05 & Cukup \\
\hline
\end{tabular}

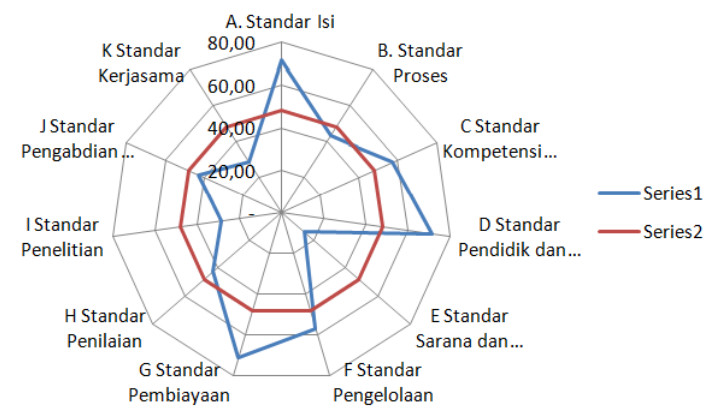

Gambar 2. Grafik Laba-laba Skor dari Standar

Berdasarkan hasil di atas, maka strategi peningkatan mutu untuk penguatan daya saing yang dapat dilakukan untuk standar yang di bawah nilai rata-rata adalah:

1. Standar proses : dapat dilakukan pengembangan mutu pembelajaran dengan membentuk unit pengkajian dan pengembangan sistem dan mutu pembelajaran termasuk proses monitoring, evaluasi, dan pemanfaatannya, yang mendorong mahasiswa untuk berfikir kritis, bereksplorasi, berekspresi, bereksperimen memanfaatkan aneka sumber yang hasilnya dimanfaatkan oleh institusi. Mengintegrasinya kegiatan penelitian dan pengabdian kepada masyarakat ke dalam proses pembelajaran. Penetapan konsep pendidikan, pengajaran, dan strategi pembelajaran serta pengembangan karakter mahasiswa. Penerapan student-centered learning,meningkatkan integrasi pelaksanaan program dan kegiatan akademik dalam pelaksanaan Tri Dharma PT. Meningkatkan pelibatan tenaga ahli/pakar sebagai pembicara dalam seminar/pelatihan, pembicara tamu dari luar PT sendiri.

Mengatur dengan baik tentang kebebasan akademik, kebebasan mimbar akademik, dan otonomi keilmuan, serta konsistensi pelaksanaannya, pengembangan suasana akademik yang kondusif bagi mahasiswa, mengembangkan kegiatan kemahasiswaan, pusat seni dan budaya bagi mahasiswa.

2. Standar Sarana dan Prasarana : Meningkatkan ketersediaan sarana dan prasarana pendidikan dengan cara mencukupkan koleksi perpustakaan, aksesibilitas termasuk ketersediaan dan kemudahan akses e-library untuk setiap bahan pustaka, pendayagunaan tempat praktikum, bengkel/sudio, ruang simulasi, rumah sakit, puskesmas/balai kesehatan, green house, lahan untuk pertanian, dan sejenisnya, ruang serba guna, tempat olah raga, ruang himpunan mahasiswa, poliklinik, ruang ibadah/doa, green area, fasilitas difable dan ruang bimbingan dan konseling. Meningkatkan ketersediaan sistem informasi dan fasilitas TIK dan blue printnya, digunakan perguruan tinggi dalam proses pembelajaran dan mengakses data dan informasi, dalam bentuk band width dengan rasio bandwidth per mahasiswa yang memadai, hardware, software, e-learning, dan on-line journal/library. Penggunaan dan pengembangan sistem informasi dalam administrasi akademik dan non-akademik yang mencakup hardware dan software.

3. Standar penilaian : Memperbaiki dan meningkatkan sistem evaluasi hasil belajar dengan ranah kompetensi lulusan yang ditetapkan, model pengukuran yang tepat. Kesesuaian Indikator-Indikator soal dengan learning outcome yang ditetapkan dalam pembelajaran dan silabus. Melakukan review soal ujian oleh komisi ujian. Meningkatkan mekanisme dan pedoman ujian TA (Tugas Akhir/ Skripsi/ Tesis/ Disertasi) dan 
Seminar Nasional Ekonomi dan Bisnis (SNEB) 2014

mekanisme/pedoman perbaikan nilai.

4. Standar penelitian : Memotivasi dosen untuk melakukan penelitian yang bermutu, yang bermanfaat bagi masyarakat, menaikan biaya untuk penelitian dan untuk mengapresiasi bagi dosen, melakukan workshop bagaimana untuk melakukan penelitian, dapat menjual hasil penelitian, bekerjasama dengan produsen untuk melakukan penelitian yang bermanfaat bagi masyarakat.

5. Standar Pengabdian Masyarakat : Meningkatkan biaya pengabdian masyarakat, mendisain pengabdian masyarakat yang sangat bermanfaat bagi masyarakat,

6. Standar Kerjasama : Meningkatkan berbagai kerjasama untuk memajukan kualitas pendidikan tinggi, output dan outcome nya

Dengan menerapkan EMI ini pada setiap perguruan tinggi di Indonesia, maka akan terjadi peningkatan mutu perguruan tinggi secara gradual, sehingga perguruan tinggi dapat meningkatkan daya saingnya baik di Indonesia maupun di ASEAN

\section{KESIMPULAN}

Secara makro, pemerintah dengan UU dan peraturan yang ada meningkatan kualifikasi dosen dan kuantitas dosen, serta meningkatakan faktor produksi lainnya dalam pendidikan. Secara mikro, setiap pendidikan tinggi dapat meningkatkan mutu pendidikannya dengan menerapkan EMI-PT secara kontinu, sehingga mutu yang sudah dicapai dapat terlihat, dan apabila dilakukan perbaikan maka akan terjadi continuous improvement. Dengan adanya peningkatan mutu perguruan tinggi maka akan memperkuat daya saing perguruan tinggi, terutama dalam menghadapai masyarakat ekonomi ASEAN.

\section{REFERENSI}

Asean University Network (AUN) .(2014, july 3). Retrieved from moveonnet.eu : http://www.moveonnet.eu/directory/network/m ap?id=AUN

Direktorat Jenderal Pendidikan Tinggi Departemen Pendidikan Nasional, 2006, Panduan Pelaksanaan Sistem Penjaminan Mutu Perguruan Tinggi (SPM-PT)Bidang Akademik.

Hutabarat, Samuel (2014) Perguruan Tinggi Indonesia dan Asean Community 2015.

http://persatuanindonesia.or.id/artikel/161perguruan-tinggi-indonesia-dan-aseancommunity. Diakses tanggal 7 agustus 2014

Kementerian Pendidikan dan Kebudayaan, 2012, Evaluasi Mutu Internal Perguruan Tinggi Indonesia, Badan Pengembangan Sumber Daya Manusia Pendidikan dan Kebudayaan dan Penjaminan Mutu Pendidikan Pusat Penjaminan Mutu Pendidikan, Bidang Pendidikan Menengah dan Pendidikan Tinggi
Nugroho (2006) Menimbang Daya Saing Perguruan

Tinggi. http://www.suaramerdeka.com/harian/ 0607/31/opi03.htm. Diakses tanggal 7 agustus 2014

Peraturan Pemerintah Nomor 19 tahun 2005 tentang Standar Nasional Pendidikan.

Panday, Rorim (2003), Performance Measurement Model For Senior Secondary School, Dissertation Doctor in Business Administration, De La Salle University

Panday, Rorim (2014a), Implementasi Penjaminan Mutu Dalam Menghadapi Globalisasi, Analisis dan Implikasi: Studi kasus, makalah pada Seminar Nasional Universitas Maranatha 2014, di Bandung

Panday, Rorim.(2014b). Quality Assurance Implementation In Higher Education To Strengthen The Innovation Strategy In Facing Globalization: A Case Study. paper presented at ICOI-2014, 12-14 agustus,, De la Salle, Manila, Philipine

Paramitha, Zaskia(2012). Pendidikan tinggi Indonesia gagal imbangi pasar.

http://nasional.kontan.co.id/news/pendidikantinggi-indonesia-gagal-imbangi-pasar. Diakses tanggal 7 Agustus 2014

Sebanyak 29 perguruan tinggi di Indonesia masuk dalam daftar 100 besar perguruan tinggi di Asia Tenggara.(2014,july 2).Retrieved from TRIBUNNEWS.COM :

http://www.tribunnews.com/internasional/2011 /02/04/inilah-peringkat-100-besar-universitasdi-asia-tenggara

Undang-undang Republik Indonesia Nomor 14 Tahun 2005 tentang Guru dan Dosen.

Undang-undang Republik Indonesia Nomor 20 Tahun 2003 tentang Sistem Pendidikan Nasional.

World Economic Forum - The Global Competitiveness Report Tahun 2013-2014.

100 Universitas Terbaik di Indonesia Terbaru 2014 .(2014, july 2$)$ retrieved from rohmatullahh.

Duduki blogspot.com: http://rohmatullahh.blogspot. com/2013/09/UniversitasTerbaikDiIndonesia20 13.html

9 Universitas di Indonesia Peringkat 300 Besar Asia.(2014, july,2). Retrieved from metrotvnews.com:http://news.metrotvnews.co $\underline{\mathrm{m} / \mathrm{read} / 2014 / 05 / 12 / 240778 / 9 \text {-universitas-di- }}$ indonesia-duduki-peringkat-300-besar-asia.

\section{Biodata Penulis}

Rorim Panday, memperoleh gelar Sarjana Teknik (Ir), Jurusan Teknik Geodesi ITB, lulus tahun 1986. Memperoleh gelar Magister Manajemen (MM) Program Pasca Sarjana STIE-IPWI, lulus tahun 1995 Memperoleh Gelar Doktor DBA dari De La Salle university, Manila, Philippine, lulus tahun 2003 dan saat ini sebagai dosen tetap di Universitas Pakuan 